\title{
NOVEL METHODS AND SOLUTIONS IN HYDROLOGY AND WATER MANAGEMENT
}

\author{
National Conference \\ (Sosnowiec and Szczyrk, Poland, 25 ${ }^{\text {th }}-27^{\text {th }}$ May, 2015)
}

On 25th $27^{\text {th }}$ May 2015 the Poland-wide conference on "Novel methods and solutions in hydrology and water management" was held in Sosnowiec and Szczyrk. It was organised under the honorary patronage of the Dean of the Faculty of Earth Sciences, Prof. dr hab. Adam Idziak. The conference was organised to commemorate a distinguished geographer and hydrologist - Professor Andrzej T. Jankowski. The organisers of the Conference included the University of Silesia - Faculty of Earth Sciences, the Centre for Polar Studies, the Polish Geographical Society - Katowice Branch, the Hydrological Commission of the Polish Geographical Society and the Association of Polish Hydrologists.

The main aim of the Conference was to exchange experiences, and present and discuss results of research concerning: innovative solutions in monitoring water quality, assessment of the ecological condition of water, the Water Framework Directive and Floods Directive as well as methodological and application problems in hydroinformatics and GIS.

In the course of the Conference, particular attention was paid to topics connected with the protection of the natural environment, and to dissemination of the results of the latest scientific research presenting current problems of contemporary hydrology, water management and ecology. Moreover, the field session and one topic session were entirely devoted to local and regional problems of water management and hydrology.

The latest developments in the methodology of hydrological measurement and water quality testing in line with the topic of the Conference were presented during the field session on the most important dam reservoir for the Silesia Voivodship - Goczałkowice on the Vistula. 63 people participated in the Conference, these representing 16 scientific centres (the Silesian University, University of Gdańsk, Warsaw University 
of Life Sciences (SGGW), University of Łódź, Central Mining Institute, Maria Curie-Skłodowska University, Jan Kochanowski University in Kielce, University of Technology and Life Sciences in Bydgoszcz, Adam Mickiewicz University in Poznań, University of Warsaw, AGH University of Science and Technology, Nicolaus Copernicus University in Torun, Institute of Meteorology and Water Management, Warsaw University of Technology and School of Administration (WSA) in Bielsko-Biała). The aims of the Conference were pursued in discussion panels, lecture and field sessions. Moreover, a volume of the reviewed Monograph of the Hydrological Commission of the Polish Geographical Society was prepared (comprising 416 pages and containing 27 chapters). 17 lectures and 11 posters were presented.

Participants in the Conference took part in three certified training sessions: "Novel methods of flow measurement in watercourses" (given by the Institute of Meteorology and Water Management), "Innovative technologies in hydrology" (given by SMART) and "Novel methods of water quality measurement" (given by OMC ENVAG). The Conference was co-funded from the pro-quality funds of the Leading National Research Centre (KNOW) received by the Centre for Polar Studies for the years 2014-2018 and from the Voivodeship Fund for Environmental Protection and Water Management in Katowice.

Damian Absalon, Magdalena Matysik, Marek Ruman Faculty of Earth Sciences, University of Silesia, Sosnowiec 